DEPÓSITO LEGAL ZU2020000153

Esta publicación científica en formato digital

es continuidad de la revista impresa

ISSN 0041-8811

E-ISSN 2665-0428

Revista

de la

Universidad

del Tunlia

Fundada en 1947

por el Dr. Jesús Emrique Lossada

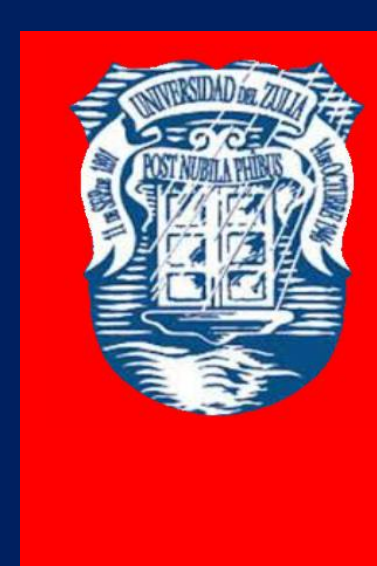

Ciencias

Sociales

y Arte

Aกัต 11 No 31

Septiembre - Diciembre 2021

Tercera ípoca

Maracailbo-Venezuela 


\title{
La conversión enunciativa del sujeto carnavalizado en las letanías del carnaval de Barranquilla
}

\author{
Luis Javier Hernández Carmona * \\ Alejandro Alberto Espinosa Patrón **
}

RESUMEN

A través del siguiente enfoque sustentado en el paradigma sociocrítico y el método semiocrítico, se propone estudiar la figuración de las letanías del Carnaval de Barranquilla a partir de los diversos planos enunciativos que interactúan mediante la construcción del sujeto carnavalizado o sujeto plural a implosionar dentro de las realidades sociohistóricas, para proponer modos alternativos de interpretar/leer los diversos acontecimientos convergidos por las variables de lo sagrado y lo profano; sistematizadas estas, a través de los espacios de la representación corpórea y los mecanismos deconstructores que crean resignificaciones estético-subversoras para anteponer ante los cánones ético-morales establecidos, otras formas de argumentar desde la parodia e ironía.

PALABRAS CLAVE: enunciación, sujeto, letanías, carnaval, deconstrucción.

\section{The enunciative conversion of the carnavalized subject in the litanies of the carnival of Barranquilla}

ABSTRACT

Through the following approach based on the socio-critical paradigm and the semi-critical method, it is proposed to study the figuration of the litanies of the Carnival of Barranquilla from the various declarative planes that interact through the construction of the carnivalized subject or plural subject to implode within the socio-historical realities, to propose alternative ways of interpreting / reading the various events converged by the variables of the sacred and the profane; systematized these, through the spaces of corporeal representation and deconstructor mechanisms that create aesthetic-subversive resignifications to put before the established ethical-moral canons, other ways of arguing from parody and irony.

KEY WORDS: enunciation, subject, litanies, carnival, deconstruction.

* Docente. Universidad de Los Andes, Venezuela. ORCID: https://orcid.org/0000-0002-74054939. E-mail: hercamluisja@gmail.com.

** Docente. Universidad Autónoma del Caribe, Colombia, espinosa200018@hotmail.com. https://orcid.org/0000-0002-5357-162X

Recibido: 06/05/2020

Aceptado: 09/07/2020 


\section{Introducción}

Asumida la carnavalización, como el momento de encuentros y desencuentros de las culturas donde los enunciantes forman parte de las fiestas públicas mediante ritos, cultos cómicos, bufones, gigantes, enanos, monstruos, payasos de diversos estilos, los cuales según Bajtín (1987) "poseían una unidad de estilo y se constituían partes y zonas únicas e indivisibles de la cultura cómica popular, principalmente de la cultura carnavalesca" (Bajtín, 1987:4), pues, además de ser manifestaciones populares que reflejaban el descontento del pueblo por los señores que los gobernaban, eran acciones de libertad del sujeto, quien amparado en las festividades, desafiaba normas y transgredía lo establecido, aunque fuera temporalmente, utilizando nuevas y variadas posibilidades enunciativas.

En este sentido la carnavalización implosiona tiempos y espacios a través de la trasgresión de reglas y normas para anteponer frente a lo establecido otras expresiones simbólicas deconstructoras de las formas enunciativas del poder; privilegiando la intervención de los enunciantes, quienes asumen la escena para promover la reflexión a través de diferentes mecanismos, que en el caso concreto de este enfoque, estarán fundamentadas en la transversalización de lo sagrado y lo profano.

$\mathrm{Al}$ respecto, acudiendo nuevamente a Bajtín (1987) podemos discernir sobre tres grandes categorías que corresponden con la cotidianidad del sujeto en la sociedad de ese entonces, las cuales refieren a:

1) Las formas y rituales del espectáculo (festejos carnavalescos, obras cómicas representadas en las plazas públicas);

2) Obras cómicas verbales (incluso las parodias) de diversa naturaleza: orales y escritas, en latín o en lengua vulgar;

3) Diversas formas y tipos del vocabulario familiar y grosero (insultos, juramentos, lemas populares.) (Bajtín, 1987: 4).

Indudablemente en las letanías del carnaval de Barranquilla están representadas estas tres categorías de prácticas sociales discursivas propias del carnaval medieval, pues se configuran mediante un mundo estético que construye referencialidades alternativas a la acción 
REVISTA DE LA UNIVERSIDAD DEL ZULIA. 3ª época. Año 11 N 31, 2020 Luís J. Hernández C. \& Alejandro A. Espinosa P.///La conversión enunciativa del sujeto... 237-260 DOI: http://dx.doi.org/10.46925//rdluz.31.16

comunicativa ordinaria ${ }^{1}$ que adquiere carácter dialógico a través de su estructura estética para comunicar lo percibido de su propia cultura y manifiesta de esta manera el desdoblamiento del enunciador-letainero en sujeto carnavalizado. Hecho por demás imprescindible en las esferas semiocríticas que evidencian los soportes de la universalidad estética con las asimilaciones locales para fortalecer el continuum semiótico, los procesos de semiotización y el afianzamiento de las relaciones de significación.

Asimismo esta yuxtaposición de lo ordinario con lo estético dentro de la acción comunicativa promueve la intensificación de los mecanismos semiotizantes del orden discursivo, puesto que, establecen la simetría simbólica tan necesaria para la rearticulación de las formas expresivas en los espacios enunciativos reconvertidos a partir de los principios estéticos que siempre conservarán su esencia autonómica a manera de acercamiento al objeto estético y su correlación con diversas posicionalidades argumentales no reducidas a la razón. Según Vauthier:

La principal tarea de la estética consiste en el estudio del objeto estético en su especificidad, pero sin sustituirlo por ninguna otra etapa intermedia del proceso de realización del mismo; y, antes que nada, es necesario entender el objeto estético de manera sintética, en su conjunto; entender la forma y el contenido en su esencial y necesaria correlación (la forma: la forma del contenido; el contenido; el contenido de la forma); entender la especificidad y la ley de esa correlación. Sólo mediante tal comprensión se puede esbozar la orientación correcta a seguir por el análisis estético concreto de ciertas obras (2004: 35-43).

Asumidas desde estas posicionalidades teóricas, las referencialidades enunciativas de las letanías del carnaval de Barranquilla están determinadas a partir de la contraposición entre lo sagrado y lo profano a modo de variables reguladoras de los procesos de significación representados por la acción comunicativa y su diversificación estética soportada por los mecanismos deconstructores de la parodia y la ironía; todas ellas, mediadas por la carnavalización como propuesta articulante de novedosas creaciones enunciativas proponentes

\footnotetext{
${ }^{1}$ Según Habermas, la acción comunicativa ordinaria no cuestiona los implícitos universales pragmáticos, sino estos son reflexionados por el discurso, que no solo cuestiona, sino también aporta razones al consenso argumentativo; pues: "La teoría de la acción comunicativa se propone además como tarea investigar la « razón» inscrita en la propia práctica comunicativa cotidiana y reconstruir a partir de la base de validez del habla un concepto no reducido de razón (1984: 506). (Resaltado en el original).
} 
REVISTA DE LA UNIVERSIDAD DEL ZULIA. 3e época. Año $11 \mathrm{~N}^{\circ}$ 31, 2020

Luís J. Hernández C. \& Alejandro A. Espinosa P.//La conversión enunciativa del sujeto... 237-260

DOI: http://dx.doi.org/10.46925//rdluz.31.16

de mundos alternativos de simbolización tendientes a reconfigurar lógicas de sentido que demanden reflexiones sostenidas por mecanismos estético-subversores, no solo de la realidad, sino de la estética misma al potenciarla dentro de los escenarios de la cotidianidad, pues este objeto estético que se encuentra en la consciencia colectiva y que funciona en tanto que es "significación".

1. El método semiocrítico para entender la conversión del sujeto en el carnaval

\subsection{La metodología}

Por tanto, es a través del enfoque semiocrítico sustentado en el paradigma sociocrítico, como se percibe esa simbolicidad comunicativa ${ }^{2}$ marcada por lo estético y el cuerpo, que mediante la construcción del sujeto carnavalizado o sujeto plural, tiende a implosionar dentro de las realidades sociohistóricas, en las cuales, se desarrollan las acciones del carnaval, de ahí que se propongan modos alternativos de interpretar/leer los diversos acontecimientos convergidos por las variables de lo sagrado y lo profano; sistematizadas estas, a través de los espacios de la representación corpórea y los mecanismos deconstructores para crear resignificaciones estéticosubversoras y anteponer ante los cánones ético-morales establecidos, otras formas de argumentar desde la parodia e ironía, por tanto, "la naturaleza de suyo puede no significar nada para el hombre; pero se vuelve significativa cuando se la inviste de afecto, lo cual se hace mediante la simbolización" (Beuchot, 2012: 6).

Por consiguiente, el sujeto, producto del carnaval de Barranquilla, corresponde con la dinámica misma de la fiesta, pues le exige un otro para participar sin dificultad en el momento histórico, revestido de la complejidad estética de los actos para develar un mundo propio, distinto, que describe la percepción de los sujetos del carnaval. Siendo estos sujetos la

\footnotetext{
${ }^{2}$ Al asumir la simbolicidad comunicativa volvemos a Habermas (1984) para significar la experiencia comunicativa asociada al cuerpo; "ante todo relativa al cuerpo y sus órganos; pues el campo de percepción está constituido en términos cinestésicos. Esa experiencia cotidiana está cortada (en términos perspectivistas) al talle de un yo con una experiencia de espacio y tiempo centrada en torno al sujeto. Además, la experiencia cotidiana se forma no sólo cognitivamente, sino en conexión con actitudes afectivas, intenciones e intervenciones prácticas en el mundo objetivo" (Habermas, 1984: 39). (Resaltado en el original).
} 
reconversión simbólica de todos los enunciantes carnavalizados en la pluralidad referencial que posibilita el encuentro a partir de la escenografía actancial tan variada como los temas a representar por medio de los procesos enunciativos.

En ese sentido se está ante la visión de mundo donde se reafirma el "yo" no como objeto de la fiesta sino sujeto que posee su propio sentido, y que su principal misión radica en su especificidad, al entender la forma y el contenido en su esencia para develar un mundo amplio que posee su propia estructura, tejido conceptual que muestra la función de los letaineros en el carnaval, su participación y lectura acuciosa de los actores en la sociedad. De esta manera asistimos a la constitución 'yoica' del enunciante a través de la participación/actuación dentro de un conglomerado profundamente alegórico para deconstruir realidades y proponer alternativas argumentales.

De manera que, la transfiguración del sujeto enunciante en sujeto carnavalizado opera a partir del reconocimiento del cuerpo plural, quien representa las posibilidades de enmascaramiento y encubrimiento para develar lo explícitamente establecido por la realidad a través de la parodia y la ironía; dos mecanismos para representar/cuestionar sostenidos por la alteridad. Además, ese cuerpo representa el escenario de la enunciación donde se materializan las relaciones de significación, siempre acontecidas por marcas indíciales que hacen implosionar los contenidos soportadas por el discurso metafórico inherente a ese cuerpo simbólico a manifestarse bajo los principios enunciativos propios de las letanías del carnaval de Barranquilla.

Por lo anterior, la percepción que desarrollan los sujetos en el carnaval corresponde con la "lectura que identificó simultáneamente al mundo en el sujeto y al sujeto en el mundo: visión que permitía entender la identidad como la coreografía entre un dentro y un afuera sin que dicha operación desvaneciera la integridad del sujeto" (Kaiser Moro, 2018, p. 136); así, el sujeto, revestido de carnaval se inserta en un espacio semiótico que lo obliga a ser otro como sí mismo, fuera de todo prejuicio para ingresar a la nueva página abierta por la fiesta, quien crea estamentos sígnicos-simbólicos para representar desde la trasgresión no solo referencial, sino corporal, bajo la asunción del cuerpo a manera de centro enunciativo.

Además, la trasgresión corporal implica la reafirmación del yo en el otro representado por las alegorías y su rol mediador con las prácticas sociales, pues representan el embrague del sujeto 
REVISTA DE LA UNIVERSIDAD DEL ZULIA. 3e época. Año $11 \mathrm{~N}^{\circ}$ 31, 2020

Luís J. Hernández C. \& Alejandro A. Espinosa P.///La conversión enunciativa del sujeto... 237-260

DOI: http://dx.doi.org/10.46925//rdluz.31.16

consigo mismo, el mundo circundante y las relaciones enunciativas. Constituyéndose bajo esta dinámica las instancias perceptivas que van a desembocar en la configuración del sujeto plural, o cuerpo simbólico desde donde van a surgir renovadas formas para percibir la realidad real y la realidad representada mediante la corporalidad carnavalesca.

Aún más, siguiendo los postulados de Greimas y Fontanille, la constitución del sujeto plural está fortalecida por la propioceptividad, quien:

Instituye una equivalencia formal entre los "estados de las cosas" y los "estados de ánimo" del sujeto. No está de más insistir aquí en el hecho de que, si las dos concepciones del estado - estado de las cosas, transformado o transformable, y estado de ánimo del sujeto, como competencia requerida por la transformación y producto de ella- se reconcilian en una dimensión semiótica de la existencia homogénea, es a costa de una mediación somática y "sensibilizante" (1994, p.p. 14-15). (Resaltado en el original).

\section{Discusión y resultados}

Lo anterior lo podemos ilustrar con la imagen siguiente, en la cual la duplicidad corporal invierte los planos perceptivos para mostrarnos la significación a través del cercenamiento del cuerpo y su refiguración dentro de lo abyecto, quien refiere a otras dimensiones de la significación que culturalmente aparece asociada con otras representaciones simbólicas, como Halloween ${ }^{3}$, donde la muerte o el tránsito hacia ella, asume condiciones de espectacularidad. Pero además de ello, representa esa dimensión semiótica homologante a través de la cual los procesos de sensibilización estética permiten la iconicidad fundante de un cuerpo manifestado en su hibridez.

\footnotetext{
${ }^{3}$ Indudablemente en Halloween podemos referir una carnavalización de lo espectral muy puntual, que a partir de la industria cinematográfica, ha creado un significativo campo semiótico y de referencialidades para alimentar la iconografía de cuerpos pluralizados a través de su migración entre la vida y la muerte, suponiendo la forma afable de convivir con lo inevitable y hacerlo espacio para la creación. Manifestaciones que indudablemente hacen parte de procesos sensibilizantes y sirven de espacios enunciativos para proponer interpretaciones soportadas por la abyección y la alteridad como atributos de una muy particular intersubjetividad.
} 


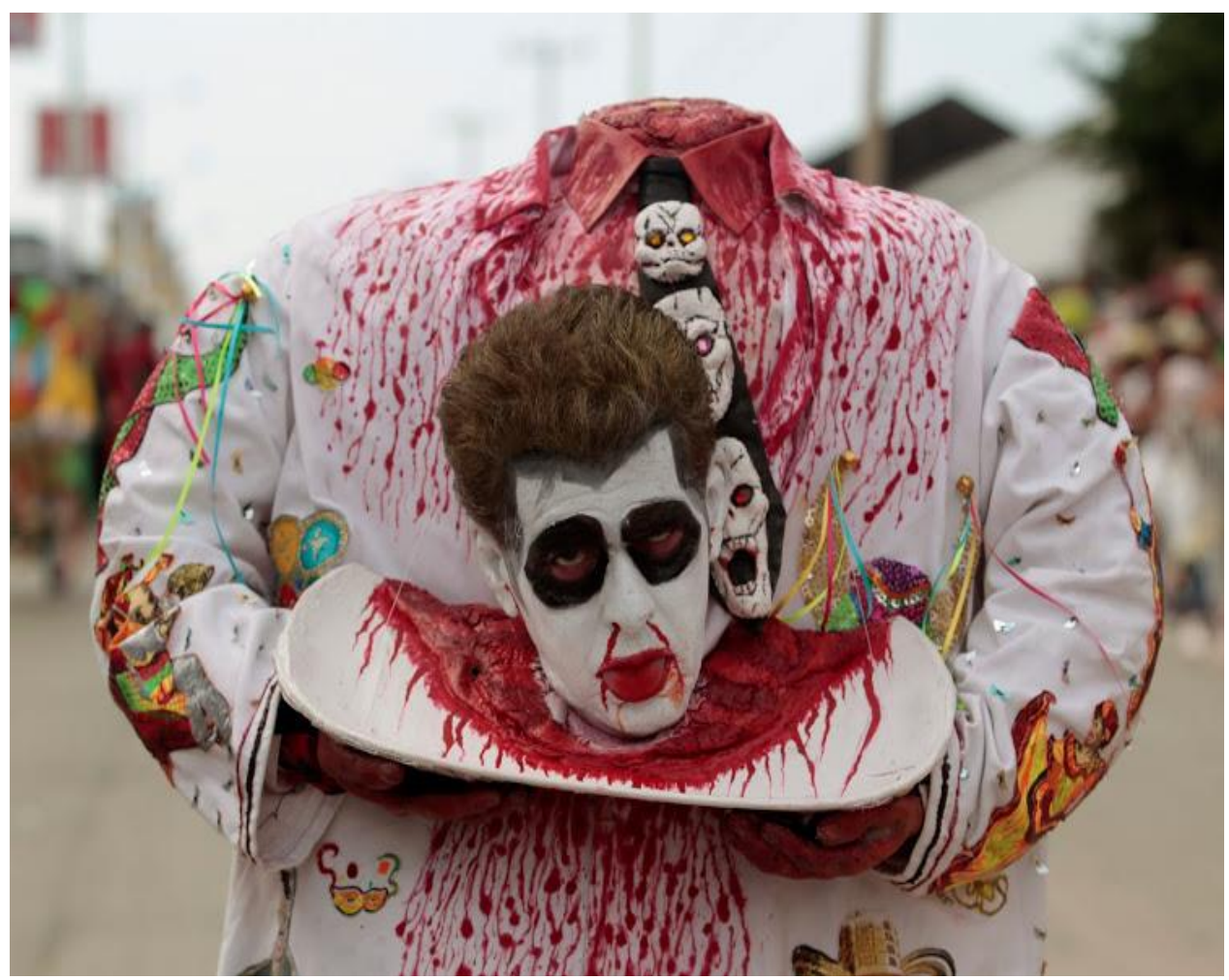

\section{El descabezado}

Fuente: Carnaval de Barranquilla, 2011.

La referida homologación corporal permite la concreción de planos enunciativos configurados por medio del dialogismo icónico generado a partir del cuerpo simbólico del sujeto carnavalizado, el cual se despoja de lo físico convencionalizado para convertirse en refiguración del sujeto mismo, la contextualización y las dimensiones alegóricas asumidas mediante los procesos semióticos de conversión simbólica, para generar una metatextualización creadora de significaciones desencadenantes de enriquecedores imaginarios socioculturales, que a su vez, permiten el ensanchamiento de los escenarios locales en universalidades estéticas cada vez más dinámicas y productivas.

Ahora bien, aquí no estamos refiriendo una estética conducente a la simple espectacularidad del acontecimiento festivo, sino que paralelamente a ella, surge el sujeto carnavalizado como materia sensibilizante para mostrar el mundo donde se revelan los hechos más impactantes de la sociedad, que en el caso específico del carnaval de Barranquilla tienen una específica figuración con enunciadores-letaineros, quienes escudriñan la realidad para 
incorporarla a su discurso paródico, transversalizado por la variable sacro-pagano (lo mundano y carnal), y resignificarla mediante los propósitos cuestionadores.

He aquí la reiteración de la mediación patémico-sensibilizante a modo de proceso semiótico caracterizado por la percepción sensible de la realidad por medio de la construcción de expresiones estéticas específicas que coadyuvan lo sagrado y lo profano en forma de letanías, o medios expresivos que permiten asociar la experiencia estética con lo profundamente humano a manera de percepción del mundo contextualizado desde diferentes perspectivas. Haciendo de lo estético una hermenéutica del enunciante-letaniero que crea una fenomenología propia de su realidad social o campo armonioso que hace parte de "la percepción sensible, la imaginación, la intelección y la emoción. Inclusive, un conocimiento emocionado, y emocionado gratamente, de modo que provoca ese disfrute por el objeto" (Beuchot, 2012:14).

Figurado bajo esta concepción de los procesos sensibilizantes, el sujeto carnavalizado incorpora la conciencia del placer a los espacios enunciativos para establecer relaciones intersubjetivas vinculadas a su corporeidad a modo de espacio del reconocimiento aun cuando rompa con la reglas de la convencionalidad social, pues la lógica de sentido inherente a los espacios festivos legitiman esa presencia trasgresora porque forma parte de su esencia simbólica, o es más, entre más escisión con la normalidad, mayores los efectos figurativos-transgresores que posibilitan la transtextualidad del cuerpo simbólico y su conversión en extra/ordinario.

Al configurarse el cuerpo sobre lo extra/ordinario la presencia del sujeto carnavalizado se hace mucho más contundente, pues logra su legitimación en los espacios de la abyección o espacios de normatización de la alteridad, con sus profundas y marcadas contextualizaciones dentro de lo ficcional a manera de convencionalidad para su figuración contenida sobre sus propias reglas o transtextualizaciones donde surge el sujeto plural entronizado dentro de los cuerpos simbólicos, tal es el caso del cuerpo erotizado, que en la contextualización del carnaval ocupa sitios de privilegio, tal cual lo muestra la imagen que sigue. 


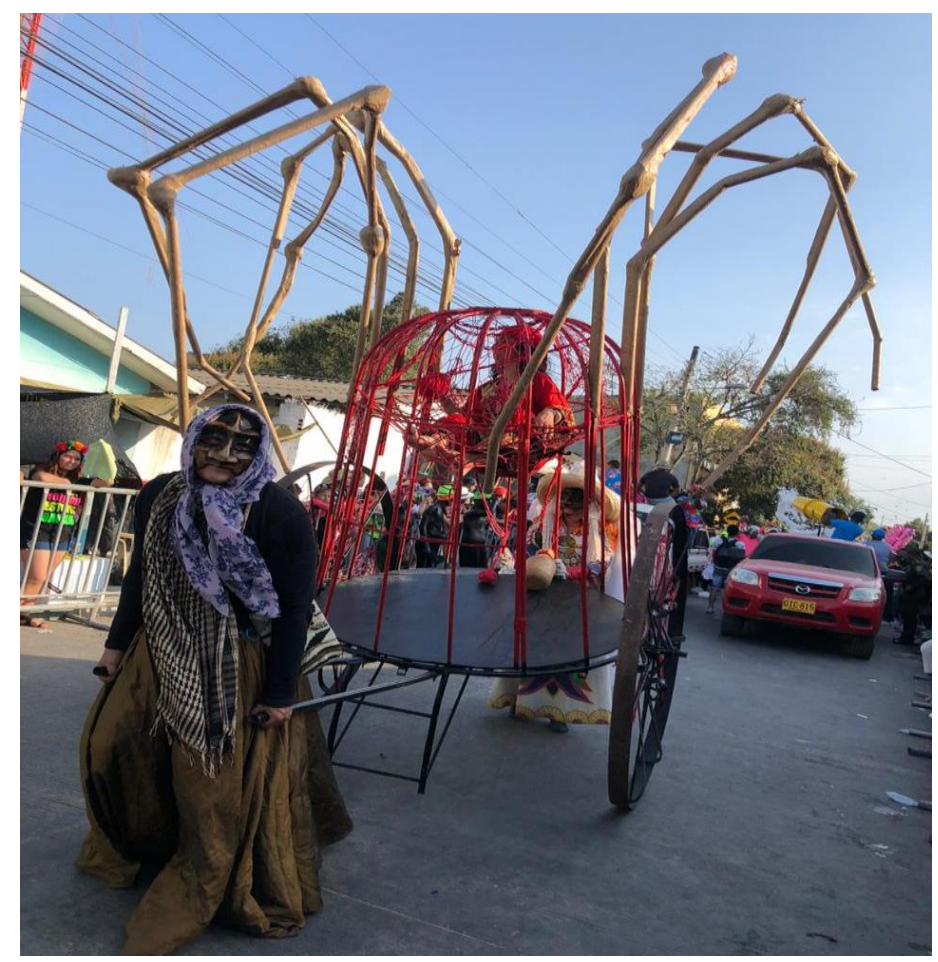

Disfraz sobre la muerte y el Coronavirus.

Fuente: Estudiantes de semiología, Universidad Autónoma del Caribe. Febrero 24 de 2020.

Carnaval y erotismo ${ }^{4}$, cuerpo y cadencia musical conforman estampas características de esta fiesta en América del Sur que se ha impuesto por el revestimiento de los cuerpos con su desnudez articulada por la profunda hibridez cultural y los movimientos característicos al ritmo de la samba. Aun cuando también debemos mencionar la hibridez mediante los cuerpos travestidos y su consiguiente trasgresión de los cánones establecidos dentro de los espacios

\footnotetext{
${ }^{4}$ Vale acotar acá que la figuración de lo erótico o los procesos de erotización referencial proveen al hombre de sistemas de reconocimiento consigo mismo y los espacios de la representación simbólica, tal y como lo ha acuñado George Bataille, con su frase: "el erotismo es lo que en la conciencia del hombre pone en cuestión al ser". (1979: 33). Y trasladándolo al sujeto carnavalizado podemos apreciarlo en la particularidad de la conciencia ética del letainero y su desdoblamiento mediante la representación actancial, encarnada por el cuerpo simbólico asumido como instrumento para direccionar el mensaje hacia el colectivo. Al mismo tiempo:

"El erotismo permite escapar de contingencia, refugiarse en la felicidad, anular el tiempo.[...] El erotismo es un refugio con relación al mundo exterior. Cuando lo olvida es, absolutamente perfecto." (Alberoni, 2000, p. 64).
} 
donde las periferias asumen los centros enunciativos para gravitar alrededor de renovadas formas de significación.

Formas de significación representadas por la eticidad transgresora-renovadora de los valores establecidos por la convencionalidad y convertidos en discursos del poder o cuerpo social institucionalizado a ser deconstruidos a través de la dialéctica simbólica del carnaval como espacio enunciativo que permite la incorporación de lo desplazado para configurar realidades alternas y de profunda contundencia cuestionadora, en la cual, la cotidianidad asume preeminencia referencial para constituir la base fundamental de las expresiones estéticas insurgentes que desafían lo instituido tanto en la transgresión de las estructuras convencionalizadas o la agregación de temas desplazados o solapados por los discursos del poder, fundamentalmente económico, político-partidista.

De esta manera, el sujeto carnavalizado es otro, "corresponde con el mundo al revés, pues se decapita a los gobernantes, se les hace inferiores y se corona a la multitud" (Eco,1990: 11-12), mediante la inversión de la verticalidad del poder por la horizontalidad creadora de la subversión estética, quien otorga licencias para la conversión en sujeto carnavalizado, transgresor de las normas sociales que se hallan por lo general prohibidas en otras épocas del año, por lo que emplea diferentes máscaras que representan a La Reina del carnaval, la Marimonda, El Descabezado, María Moñitos, Joselito Carnaval, Monocuco, Cantinflas, La Loca, Disfraz de muñecotas y cabezones, Negras Palenqueras o bien bollonga, Disfraz del Africano, entre otros que indican la conversión del sujeto, pues su sensibilidad por el contexto brota en los atuendos que escoge para representarse en la fiesta.

Todas ellas representaciones o mixturas simbólicas del cuerpo pluralizado por disimiles caracterizaciones, entronizado en paradójicas iconografías que potencian los niveles de significación-transgresión, específicamente cuando se trata de constructos históricos, donde el cuerpo inamovible del bronce conmemorativo cobra vida e irrumpe la cotidianidad para universalizarse en alas del sujeto carnavalizado o la intemporalidad histórica que permite romper con las ataduras cronológicas o los sesgos de la discriminación cultural, para promover la convivencia mediante la pluralización de los actantes configurados más allá de la simple 
REVISTA DE LA UNIVERSIDAD DEL ZULIA. 3e época. Año $11 \mathrm{~N}^{\circ}$ 31, 2020

Luís J. Hernández C. \& Alejandro A. Espinosa P.///La conversión enunciativa del sujeto... 237-260

DOI: http://dx.doi.org/10.46925//rdluz.31.16

realidad; contextualizados en las circunstancialidades recurrentes del arte y el ingenio que en los escenarios carnavalescos encuentra los espacios de la autenticidad.

Por lo que se debe hace hincapié en la colateralidad entre la conversión del sujeto carnavalizado y la mixturización cultural que va a sentar bases para el dialogismo intercultural como acción comunicativa que posibilite la preservación, ensanchamiento y proyección de las manifestaciones locales en una universalidad identitaria que permita la interacción por medios diferentes a los establecidos y donde la figuración patémica, provea de placer y consustanciación a los sujetos enunciantes como mecanismos de referencia central de las relaciones de significación.

En todo caso el sujeto carnavalizado implica una constitución 'yoica' a través de lo llamado por Foucault la autosubjetivación, o la vía de tomar conciencia del sujeto desde él mismo en profunda correspondencia con el reconocimiento individual/colectivo. Reconocimiento que en este caso vienen dado por la asunción de la corporeidad simbólica propia de la representación carnavalesca, por ello, reconocemos que:

Esas relaciones que uno tiene consigo pueden tener la forma de actos. Por ejemplo: protegemos el yo, defendemos el yo, lo armamos, lo equipamos, de actitudes: respetamos el yo, lo honramos. Y finalmente, pueden asumir en cierto modo, la forma de una relación de estado: uno es dueño de sí, posee su yo, lo hace suyo (relación jurídica). E incluso: uno experimenta en sí mismo un placer, un goce o una voluptuosidad. Como ven la conversión que se define aquí es un movimiento que se dirige hacia el yo, que no le quita los ojos de encima, que lo enfoca de una vez por todas como un objetivo y que finalmente lo alcanza o vuelve a él (Foucault, 2012, pp. 213-214).

De esta manera la conversión enunciativa siempre estará dirigida al yo como centro o núcleo referencial de todas las acciones a constituirse en función de la materialización de las imágenes alegóricas de las diferentes instancias representacionales del sujeto transfigurado en otro plano de la significación. De allí nuestra puntualización del sujeto carnavalizado a modo de convergencia sígnico-simbólica que permite, desde el método semiocrítico, diversificar apreciaciones argumentativas, donde los constructos históricos cohabitan con los ficcionales para crear iconografías muy particulares, y por demás, representativas, como la imagen que a continuación se muestra: 


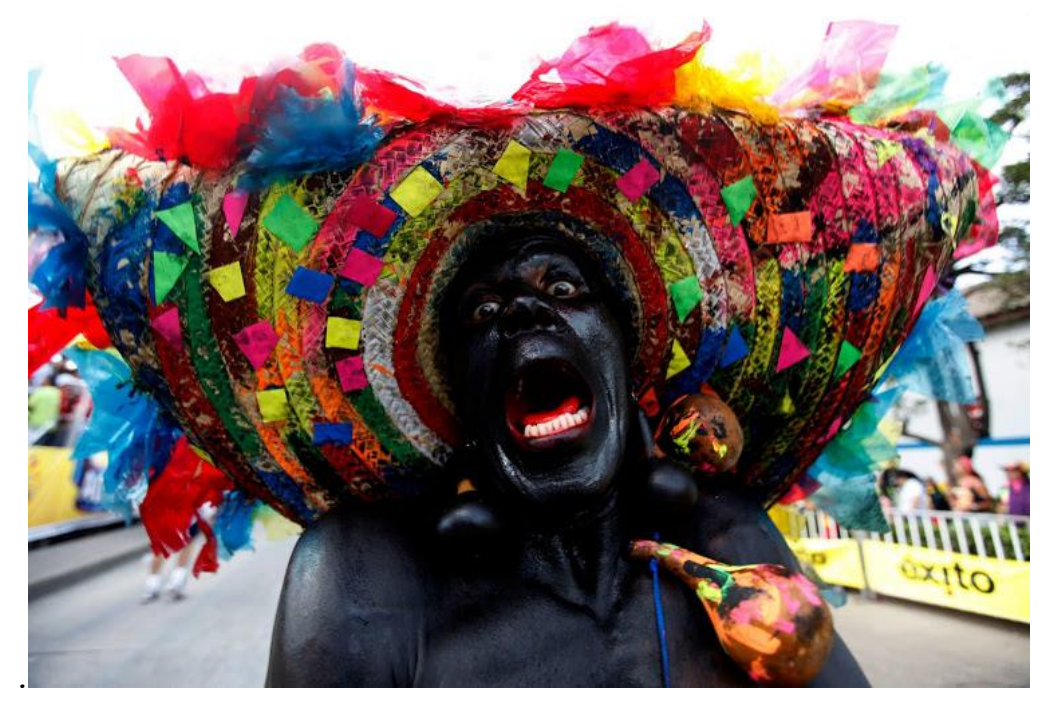

Disfraz del Africano

Fuente: Carnaval de Barranquilla 2011.

Imagen donde la mixtura icónica apuntala la referencialidad para conjuntar cuerpos de la periferia histórica con el presente representacional que reactualizan su presencia, o desde ella, rompen esquemas establecidos por las realidades sociohistóricas. De allí que una base referencial -negroide- sea revestida de la policromía visual y la gestualidad para implicar la irrupción de la subversión de las formas en medio del espectáculo festivo del carnaval, en el cual, las conversiones de los sujetos carnavalizados crea sus propias referencialidades y consiguientes lógicas de sentido.

Proyectado a partir de esta perspectiva, el carnaval asume la configuración de una macrosemiosis profundamente enriquecida por diversos ejes que al sustentarse en la conversión enunciativa del sujeto debe crear formas enunciativas que conlleven a la materialización del cuerpo simbólico, quien a su vez estatuye formas expresivas fundamentadas por la codificación desacralizadora o punto de implosión central de las realidades representadas -verbalizadas y no verbalizadas-. Dentro de las estas formas expresivas, además de la gestual-corporal, están las letanías o instrumento lexical-simbólico para parodiar realidades y desacralizar situaciones de diferente índole.

Siguiendo los postulados lotmanianos, el carnaval configura una semiosfera para que los sujetos interaccionen culturalmente mediante la textualización sígnica y dinámica que sirve de 
REVISTA DE LA UNIVERSIDAD DEL ZULIA. 3e época. Año $11 \mathrm{~N}^{\circ}$ 31, 2020

Luís J. Hernández C. \& Alejandro A. Espinosa P.///La conversión enunciativa del sujeto... 237-260

DOI: http://dx.doi.org/10.46925//rdluz.31.16

escenario para la circulación de la significación. Espacio semiótico sin el cual es imposible la existencia misma de la semiosis, por eso la transformación del sujeto y su correspondiente aceptación por la sociedad dentro de los espacios de la burla y la ironía, al homologar planos enunciativos de lo sacro y lo profano para reclamar la existencia de un ser que trasgrede lo establecido a través de sus acciones.

La homologación referencial por medio de la conjunción de los planos enunciativos hace que las acciones contenidas por las representaciones impliquen la simbolicidad de la fiesta enmarcada en otro ser que aviva el momento histórico, lo transforma y lo proyecta para que no sea repetitivo, sino actual por las temáticas que surgen, constituyéndose de esta manera la base de la teoría a través de la cual Beuchot (2012) señala al ser como un símbolo,

(...) porque el símbolo es el signo que encierra un significado profundo, oculto, además del superficial y evidente que contiene. Incluso, ese significado escondido es analogado más principal que el otro, manifiesto. Ese significado atemático es tal porque es un significado para el hombre, es lo que hace al ser significativo para el ser humano, le dice algo y algo muy fundamental. Ese significado fundamental, o de fundamento, no parece una cuestión puramente ontológica, metafísica; parece trascender ese ámbito. Algunos lo han encontrado en el ámbito de lo religioso, pero está más al alcance en el ámbito de lo estético. Lo estético es, así, una de las fuentes de sentido del ser, uno de los lugares simbológicos, donde reluce la simbolicidad del ser, su carga simbólica o su condición de símbolo; es un topos o tópico privilegiado en el que el símbolo (sentido, belleza, plenitud) se nos manifiesta y brilla (Beuchot, 2012: 78-79).

Aún más, la conversión del sujeto en símbolo -carnavalizado- permite la hibridación no solo temática sino estructural para que de esa forma surjan las expresiones estéticas contentivas de los recursos propios del discurso metafórico, que en el caso de las letanías del carnaval de Barranquilla, es de esencial fundamentación como lo significaremos en el próximo aparte de este acercamiento teórico-metodológico.

Ahora recurriendo a los lugares simbológicos aludidos por Beuchot (2012), los escenarios carnavalescos están fundamentados en la hiperficcionalización como recurso de estructuración de las situaciones representadas. Entendida la hiperficcionalización a modo de potenciación del 
constructo ficcional a través de diversos recursos estético-expresivos, entre ellos la re-creación ${ }^{5}$ referencial, que en la iconografía fílmica cuenta con una inagotable fuente de sostenimiento, tal y como se puede observar en las imágenes que ilustran esta parte del trabajo.

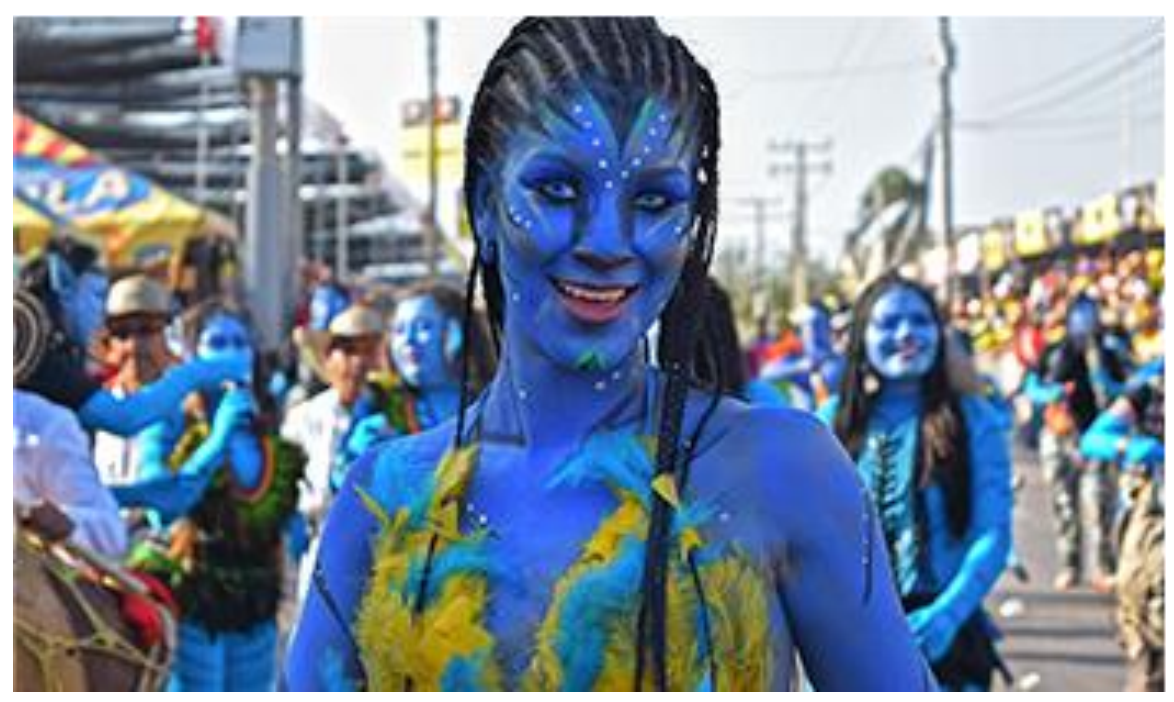

Disfraz de Avatar

Fuente: Carnaval de Barranquilla 1993

\subsection{Del sujeto estético al cuerpo con sentido simbólico}

Como se ha referido anteriormente, la conversión ${ }^{6}$ del sujeto está mediada no solo por lo estético sino por el cuerpo, instrumento y complemento de la conversión, sujeto carnavalizado, pues el cuerpo se hace ente perceptible e inteligible que adquiere dos dimensiones: corporal y corpórea. La primera estaría representada por características biofísicas que lo identifican, mientras que su corporeidad estaría definida por sus rasgos de naturaleza social o semióticas, a

\footnotetext{
5 Re-creación para puntualizar la dialéctica estética confluida en la resignificación de los acontecimientos provenientes del constructo ficcional, quienes conservan la esencia sígnica original contrastada con la realidad como proceso semiótico de adaptación

${ }^{6}$ Tal inversión ha sido interpretada por muchos especialistas como una estrategia social que sirve para aliviar los conflictos y tensiones latentes entre los miembros de cada comunidad, especialmente entre quienes ejercen el poder y quienes lo sufren; como una especie de catarsis, en definitiva, que permite la expresión ordenada, reglada y temporal, durante un período concreto y limitado de tiempo, de las pasiones y tensiones reprimidas durante el resto de año, lo que, al fin y al cabo, refuerza la continuidad de la estructura socio-política y cultural de la comunidad (Berzosa, S.f)
} 
través de sus manifestaciones: icónicas, indíciales y simbólicas. Por lo que podemos decir junto con Fontanille (2017) que el cuerpo, desde la poética, "es ante todo la sede de la experiencia sensible y de la relación con el mundo en cuanto fenómeno, en la medida en que esa experiencia puede prolongarse en prácticas significantes y en experiencias estéticas" (Fontanille, 2017: 16), y desde el constructo semiocrítico, el cuerpo es un profuso cartograma simbólico que posibilita la rearticulación de relaciones de sentido y postulaciones argumentales representadas por la dinamia intersubjetiva como formas de irradiación semiótica para vincular: sujetos, acontecimientos y contextualidades a manera de formas de 'leer' el mundo o vinculaciones de la socialidad; a decir de Fontanille:

Simultáneamente uno de los vectores de la socialidad y de la relación con el otro, el objeto y soporte de prácticas terapéuticas, rituales y simbólicas, el anclaje principal de las lógicas de lo sensible, y de las formas de las relaciones semióticas con el mundo que lo rodea, características de cada cultura (Fontanille, 2017: 18).

E indudablemente una de las formas características de estas lógicas de lo sensible vienen dadas por la articulación entre las alegorías telúricas y los procesos de conversión del cuerpo simbólico, el cual acude a la humanización para recurrir en procesos estéticos constituyentes de imaginarios socioculturales. De esta manera la tierra alegorizada por su esencia originaria deriva simbólicamente a través de los arquetipos fundacionales legados a través de la tradición ritual de las culturas fundacionales encarnadas en el politeísmo y el culto a los animales, fenómenos naturales y todos aquellos referentes atribuyentes de la esencia identitaria.

De hecho todas las personificaciones a través del cuerpo carnavalizado que aluden a animales están soportadas por una profunda base telúrica que hace reingresar a los tiempos de la representación carnavalesca, cimientos originarios a reactualizarse mediante la figuración corpórea que vincula tiempos en apariencia desvinculados, pero por interrelación intersubjetiva apelan a la lógica de lo sensible para establecer presencia y significación en un momento determinado del acto enunciativo. Hecho que podemos apreciar bajo múltiples detalles en la siguiente imagen y su profunda simbiosis telúrica-referencial. 


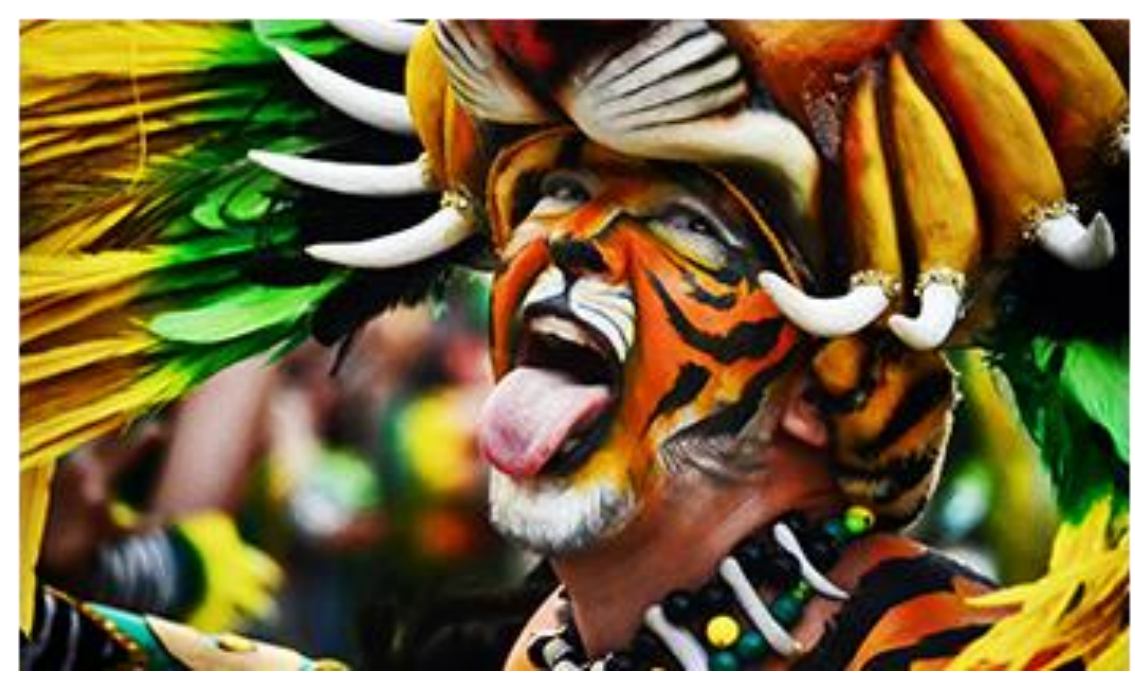

Disfraz sobre el león de la selva africana

Fuente: Carnaval S.A.

Bajo estos procesos de homologación alrededor del cuerpo son posibles los amalgamientos en unidades simbólicas como analogías del discurso práctico presente en casi todas las interacciones o prácticas humanas conducentes a la satisfacción de necesidades corporales, sociales, culturales e integración colectiva. No obstante, hay que añadir las necesidades subjetivas estructurantes de las lógicas de lo sensible articuladas por lo afectivosubjetivo significadas por la ontosemiótica en sus postulados centrales. En este sentido el carnaval convoca lo polifigurativo como práctica social transitiva que ofrece al cuerpo una amplia variedad de posibilidades para presentar y representarse a sí mismo y al mundo.

Específicamente en el carnaval de Barranquilla y dentro de la dinamia enunciativa de las letanías, el cuerpo juega un papel determinante al representar junto con el lenguaje verbal, la complementariedad de la acción comunicativa, pues ambos se complementan al hacer uso de su polifonía corporal, evento que se constata en el performance de la letanía diversificada desde lo lexical-simbólico hasta la gestualidad o histrionismo, en el cual queda convergido enunciativamente el sujeto carnavalizado que sirve de recipiendario de las distintas interpretaciones a articularse mediante la representación carnavalesca.

En las letanías del carnaval de Barranquilla, evento que ha estado presente en los últimos años, el cuerpo se convierte, pues, en recurso sígnico a partir del cual se van a generar las operaciones semióticas que comunican desde los gestos, las posturas, los movimientos pausados 
en el escenario que invade la cotidianidad, o más bien la cotidianidad se rearticula en su espectacularidad desacralizadora para crear otros espacios de la simulación donde lo sacro cede paso a la ritualidad alternativa que cuestiona a través de la ironía y la parodia. Por lo que los letaineros pasan a convertirse en ejecutores del ritual carnavalesco, que partir del humor llama a la reflexión.

Lo hacen al levantar los textos con las dos manos hacia el cielo como si estuvieran en una iglesia, como implorando, combinándose con el uso de entonaciones que suben y bajan al compás del volumen de la voz, y que corresponden con el cuerpo que trasciende con su presencia para convertirse en el medio para avanzar en el discurso irónico que presentan los letaineros enunciadores, es decir toda una gestualización como paralelismo significante que conduce al centramiento de la realidad parodiada, al convocar todos los iconos de ésta para reconfigurar el acontecimiento pretendido. Además de comportar dentro de la estructura lexical-simbólica todos los referentes estilísticos propios de esas expresiones sacras que apelan a la musicalidad para acompasar la ritualidad-

Por tanto, estudiar el cuerpo desde las letanías del carnaval de Barranquilla, permite comprender las acciones discursivas en un espacio donde los sujetos letaineros enuncian a través de la ironía y la burla lo que está sucediendo en su mathesis. Ellos emplean el cuerpo como mecanismo semiótico para reafirmar el sentido que surge de su representación, pues se convierte en escenario de la significación más allá de la literalidad. Consustancia la cadena hablada a través de la corporeidad representacional.

En tal sentido las letanías representan con su percepción social los avatares de un mundo caricaturizado para indicar con sus gestos y discurso verbal cómo entienden su espacio, cuáles son los sujetos que lo conforman, qué dicen con su cuerpo o representación-enunciación que expresa otra modalidad dentro de los procesos de comunicación mediados por la acción estética "no obstante aquella "catástrofe" cultural y humana - algo melancólica y real - abrirá la posibilidad de pensar otros destinos de la alteritas y que no dejará de insistir respecto de "limitar" lo extralimitado y de "inventar" otro orden de cosas, tanto del mundo como en la propia subjetividad," (Cabrera Pérez, 2015: 13), pues no debe descartarse "el cuerpo como memoria 
REVISTA DE LA UNIVERSIDAD DEL ZULIA. 3e época. Año $11 \mathrm{~N}^{\circ}$ 31, 2020 Luís J. Hernández C. \& Alejandro A. Espinosa P.///La conversión enunciativa del sujeto... 237-260 DOI: http://dx.doi.org/10.46925//rdluz.31.16

histórica, memoria mítica, memoria íntima, el deseo, la compatibilidad y la tolerancia" (Hernández, 2014:235), sino más bien, incorporarlo en su patemia creadora.

En consecuencia, el cuerpo es la manifestación de una cultura, una construcción social que la hace propia por su misma acción comunicativa conteniente de lo pretendido y expresado, que trasciende a través de las letanías sustentadas por los mecanismos de la burla, pero también con el cuerpo a modo de revelación de un mundo diferente develado en los planos enunciativos. De esta forma, la presencia del cuerpo letaniero en ese aquí y ahora, cada año que se celebra el carnaval, confiere un espacio provisorio, pero propio, y permite ahondar en su temática crítica y denunciante, para romper con la cuadriculación de los espacios cotidianos aludida por Foucault:

(...) vivimos, morimos, amamos en un espacio cuadriculado, recortado, abigarrado, con zonas claras y zonas de sombra, diferencias de nivel, escalones, huecos, relieves, regiones duras y otras desmenuzables, penetrables, porosas; están las regiones de paso: las calles, los trenes, el metro; están las regiones abiertas de la parada provisoria: los cafés, los cines, las playas, los hoteles; y además están las regiones cerradas del reposo y del recogimiento $(2008$, p. 3).

Por tal motivo, el cuerpo como construcción social permite a los enunciadores letaineros acercarse a otras formas de comunicar, pero también a otras maneras de significar bajo un mundo semiótico que describe sus acciones para llegar a un mensaje que revela cómo el sujeto entiende su contexto para ironizar en torno a los sujetos, pues ellos pueden ver el cuerpo, también desde lo grotesco, como punto de inicio de las imágenes ambivalentes de la sociedad.

(...) la estética de la vida cotidiana preestablecida y perfecta, parecen deformes, monstruosas y horribles; el coito, el embarazo, el alumbramiento, el crecimiento corporal, la vejez, la disgregación y el despedazamiento corporal, etc. Son imágenes que se oponen a las clásicas del cuerpo humano perfecto y en plena madurez, depurado de las escorias del nacimiento y el desarrollo (Bajtín, 1999: 29).

Por tanto, en el cuerpo surgen otras representaciones enunciativas que muestran lo grotesco, horroroso para el enunciador letaniero, por lo que se ha convertido en instrumento para señalar la realidad a partir de la subversión estética-referencial, a través de la cual:

(...) lo grotesco se vuelve un arma subversiva, una forma de confrontar los ideales establecidos para así mostrar una cara de la realidad que nos es maquillada, ocultada, 
o eliminada. "Un arma agresiva," (...) el efecto de shock de lo grotesco puede también ser usado para desconcertar y desorientar, paralizar al lector, sacudirlo de su forma cotidiana de percibir el mundo y confrontarlo con una perspectiva radicalmente distinta y perturbadora" (López, 2015:88).

De allí que es posible la inserción de referencialidades desplazadas por las convencionalidades sociales para significar a través de otros planos enunciativos no sujetos a una regulación temporal, pues los escenarios carnavalescos están caracterizados por la trasgresión de las normas e incorporación de lo excluido como principios de la espectacularidad, quien a su vez, pasa a convertirse en el gran legitimante de la ironía y la parodia para crear mediante la disimilitud espacios de la significación. A partir de la pertinencia de la disimilitud se hace la inclusión de referencialidades desplazadas como la muerte, la deformidad corporal, el travestismo, o la investidura grotesca de personajes públicos a través de vestimentas alusivas a un hipotético destino por su actuación no muy transparente -un político vestido de prisionero-.

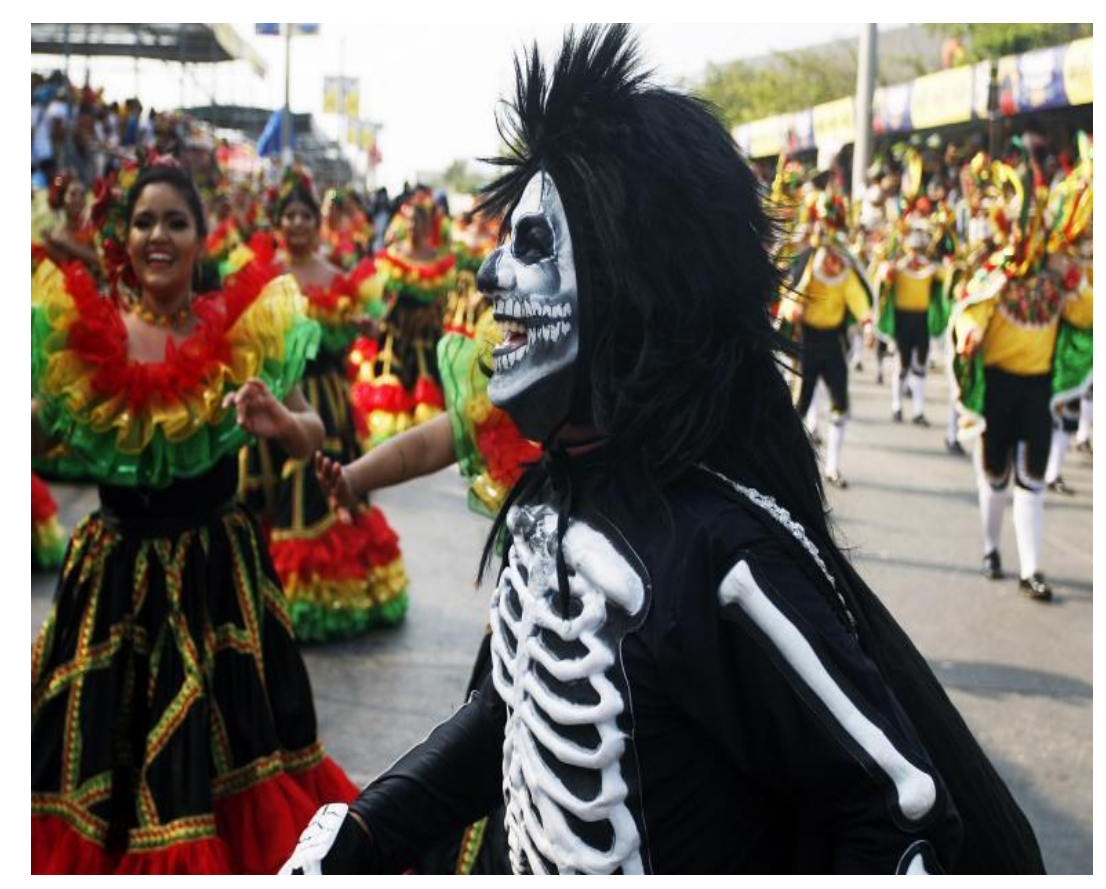

Disfraz de la muerte

Fuente: Eltiempo.com Carnaval de Barranquilla 2019. 
REVISTA DE LA UNIVERSIDAD DEL ZULIA. 3e época. Año $11 \mathrm{~N}^{\circ}$ 31, 2020 Luís J. Hernández C. \& Alejandro A. Espinosa P.///La conversión enunciativa del sujeto... 237-260 DOI: http://dx.doi.org/10.46925//rdluz.31.16

Es evidente entonces que el sujeto enunciador utiliza los procedimientos estéticos de lo grotesco para implosionar los espacios de la significación desde diferentes planos enunciativos, al encubrir su cuerpo de colores e indumentarias contrastantes con los cánones establecidos, para esgrimir la corporeidad como representación enunciativa de las letanías para convocar la constitución del sujeto carnavalizado en instrumento para reconocerse, ser reconocido y reconocer al otro en los planos de la significación alterativa, cuestionadora e impulsora de reflexión a través del entrecruce de lo sagrado y lo profano.

Por lo anterior, es a través de los mecanismos deconstructores que se crean resignificaciones estético-subversoras para anteponer ante los cánones ético-morales establecidos, otras formas de argumentar desde la parodia e ironía, porque el sujeto carnavalizado entra en el deseo individual de perder su identidad, porque para Flores (2001) ser el otro para:

Convertirse durante un día por completo en otra persona, es el núcleo de la experiencia del carnaval. Además, es de todos conocida la vinculación de la máscara —en tanto que soporte material- como símbolo por excelencia del carnaval, como medio para "revelar" los deseos ocultos, y permitir la desinhibición del sujeto (2001, p. 40).

Por tal motivo, el análisis semiocrítico plantea desde el sujeto carnavalizado y los grupos de letanías como objeto de análisis, la proyección de la alteridad o transformación desde los planos enunciativos para penetrar en la historia y los constructos del tiempo mediante el "sentimiento" o la "experiencia de sí” y su opacidad interpelante" (Cabrera Pérez, 2015:10-11), pues sus actos develan un mundo profano encubierto por la máscara para expresar la otra faz y alteridad del ser humano. Por tanto, a través del enfoque planteado se puede develar la posición crítica del sujeto, su percepción del mundo, sus vivencias para proyectárselas a los otros, dado que en el proceso hermenéutico de la selección de las temáticas, las situaciones y los momentos, los enunciadores letaineros podrán situar a los enunciatarios en contexto para que el mensaje sea claro y contundente.

En síntesis, se está ante una nueva percepción hermenéutica de comprender las aristas del texto, y penetrar en un espacio, cargado de alteridades que sirven para mirar en detalle sus células epidémicas, núcleos temáticos, citoplasmas semióticos y membranas, que lo hacen complejo ante la mirada de los otros. Es decir, se está ante otras ventanas semióticas para ingresar 
REVISTA DE LA UNIVERSIDAD DEL ZULIA. 3e época. Año $11 \mathrm{~N}^{\circ}$ 31, 2020 Luís J. Hernández C. \& Alejandro A. Espinosa P.///La conversión enunciativa del sujeto... 237-260 DOI: http://dx.doi.org/10.46925//rdluz.31.16

en los textos y develar su estructura y fases de significación, por lo que la conversión del sujeto carnavalizado es el mejor ejemplo para entender la presencia de los disfraces en un mundo donde cada día surgen otras manifestaciones o máscaras cotidianas marcadas por la violencia y la mentira de los sistemas económicos imperantes. Así, El sujeto no solo se convierte en el carnaval, sino que ya viene convertido en el otro, el que el sistema forjó y encuentra en la fiesta la válvula de escape, de oxígeno para mostrar lo que realmente quiere ser trasmutado en el sujeto carnavalizado o sujeto de la pluralidad donde residen las posibilidades de conversión semiocrítica.

\section{Conclusión}

Bajo las perspectivas del método semiocrítico hemos dejando en evidencia la conversión de un sujeto carnavalizado a través de las letanías del carnaval de Barranquilla y sus consiguientes desdoblamientos enunciativos, donde el cuerpo o los mecanismos de corporeización semiótica permiten la incursión de renovadas formas de argumentación, al reconocer en la pluralidad sígnica-simbólica la conjunción de disímiles y sincréticos elementos, que al interactuar, crean imaginarios socioculturales determinantes al momento de apelar a la sociosemiótica o semiótica crítica de la cultura para intervenir la compleja macrosemiosis de la representación carnestolenda.

La reiterada conversión enunciativa diversifica los ejes interactuantes alrededor de los diferentes escenarios o centros generadores de la significación, reiterando al cuerpo como el centro de configuración semiótica, al apelar a la interacción de sus elementos constituyentes desde la materialización de la imagen hasta la figuración simbólica-metafórica, quien asume las bases generadoras de las referencialidades que lindan entre la realidad y la ficción para aglutinar en un mismo constructo las posibilidades de interacción por medio de la vinculación sagradoprofana.

Contrapuestos estos dos planos enunciativos para el surgimiento de realidades alternativas, las letanías del carnaval de Barranquilla no solo establecen su propio universo simbólico subversor, sino que asumen los procedimientos estéticos a manera de codificación soportada en la ironía y la parodia para contraponer referencialidades a lo establecido como 
discursos del poder convencionalizados social, histórica y culturalmente mediante acciones comunicativas soportadas por la razón desconfigurante de los principios y valores sensibles de los sujetos.

Por lo que surge una variable de vital importancia para este enfoque, devenida de la incorporación de lo sensible a la conversión enunciativa del sujeto carnavalizado a través del reconocimiento en un yo plural revestido por la homologación de todas las acciones yoicas concurrentes dentro de la realidad representada por la dinámica carnestolenda. Dinámica a efectivizarse a medida que transcurre la acción comunicativa por los tránsitos simbólicos de las diversas semiosis constituyentes de las letanías del carnaval de Barranquilla y su circulación por los espacios de la significación.

De esta forma la conversión enunciativa del sujeto carnavalizado implica la concreción semiocrítica de un complejo proceso de reconversión simbólica apuntalado por diversos ejes temáticos que interactúan alrededor del cuerpo desplegado en sus dos alternativas fundamentales: la máscara o el encubrimiento, y la revelación polifigurativa más allá de la simple imagen proyectada en medio de la ritualidad carnestolenda; ritualidad a modo de coadyuvante de significación para significaciones alternativas y subversoras del orden establecido, quien a través de la parodia y la ironía, confluye entre lo sagrado y lo profano para sistematizar lógicas de sentido más allá de la simple literalidad de la imagen.

En síntesis, las letanías del carnaval de Barranquilla construyen semiosis concatenantes de la significación para enriquecer la macrosemiosis festiva y la estructuración de determinados códigos simbólicos al conjuntar la tradición local con la figuración universal, que permite unir los tiempos y espacios históricos en presentes narrativos caracterizados por la escisión de las convencionalidades mediante la incorporación de las lógicas sensibles para ramificar al lado del sujeto toda una compleja conversión en el rol de carnavalizado o instancia de la representación semiótica.

Con base en esta argumentación semiocrítica, el sujeto carnavalizado opera como instancia de pluralización referencial para constituir el cuerpo simbólico que interpreta en sus especificidades icónicas, los acontecimientos por medio de la transferencia real-ficcional y la creación de imaginarios socioculturales o universos alternativos para significar desde la coalición 
REVISTA DE LA UNIVERSIDAD DEL ZULIA. $3^{\text {a }}$ época. Año 11 N³1, 2020

Luís J. Hernández C. \& Alejandro A. Espinosa P.///La conversión enunciativa del sujeto... 237-260

DOI: http://dx.doi.org/10.46925//rdluz.31.16

de lo sagrado y lo profano otras formas de argumentar o leer el mundo a través de la conversión de un sujeto cotidiano en carnavalizado bajo las constelaciones semióticas de la enunciación.

\section{Referencias}

Alberoni, Francesco (2000). Elerotismo. España: Gedisa, S.A.

Bajtín Mijaíl M. (1978). Problemas de la poética de Dostoievski. Fondo de cultura económica. México.

Bajtín, M. (1987). La cultura popular en la Edad Media y Renacimiento. Barcelona: Seix Barrai, 1974.

Bajtin, M. (1999). La cultura popular en la Edad Media y el Renacimiento: El contexto de François Rabelais. Trans. Julio Forcat y César Conroy. Madrid: Alianza.

Bataille, Georges (1979) El erotismo. España: Tusquets Editores.

Berzosa Guillén Dimas Luis (s.f) Carnaval. En línea: http://losrelatosdesamid.blogspot.com/2013/01/carnaval.html

Beuchot Mauricio (2012). Belleza y analogía. Una introducción a la estética. Editorial san Pablo.

Cabrera Pérez Pablo (2015). "Freud: indagaciones en torno al sujeto, la alteridad y la experiencia". Universidad de Chile, facultad de artes, escuela de Postgrado. Tesis para optar al Grado de Doctor en Filosofía con mención en Estética y Teoría del Arte.

Carnaval de Barranquilla. (Imágenes) En línea: https://www.carnavaldebarranquilla.org/tradicion/ consulta: 3 de febrero de 2020.

Eco, Umberto; Ivanov, V. V.; Rector Mónica (1990). iCarnaval! Editorial, Fondo de Cultura Económica.

Flores Martos, Juan Antonio (2001). Un Continente de Carnaval: Etnografía Crítica de Carnavales Americanos. Universidad de Castilla-La Mancha.

Fontanille, J. (2017). Soma y sema: figuras semióticas del cuerpo. Lima: Universidad de Lima.

Foucault, Michel (2012). Hermenéutica del sujeto. Curso en el Collége de France (1981-1982), $5^{\circ}$ reimpresión, Fondo de Cultura Económica: México.

Greimas, Algirdas, Fontanille, Jacques (1994). Semiótica de las pasiones. De losestados de la cosas a los estados de ánimo. México. Siglo Veintiuno Editores. 
Habermas, Jürgen (1984). Teoría de la acción comunicativa: complementos y estudios previos. Madrid. Cátedra.

Hernández Carmona, Luis Javier (2014). La pedagogía de la sensibilidad y los acercamientos al sujeto descentrado. Educere. Vol. 18, núm. 60, mayo-agosto, pp. 229-236. Universidad de los Andes, Mérida, Venezuela.

Hernández Carmona, Luis Javier (2015). Cuadernos de Literatura del Caribe e Hispanoamérica $\bullet$ ISSN 1794-8290 • No. 21 • Enero-Junio • $179-197$.

Imágenes tomadas de Carnaval de Barranquilla. Consulta: 12 de enero de 2020.

Imágenes tomadas de Eltiempo.com. En línea: https://www.eltiempo.com/colombia/barranquilla/los-mejores-disfraces-del-carnaval-debarranquilla-2019-333894

Kaiser Moro, Andrea (2018). Sujeto, conciencia y guion de cine. Universidad de Granada, España. López Get, Anthony (2015). Lo grotesco y el arte contemporáneo latinoamericano. Reflexiones, vol. 94, núm. 1, pp. 81-96 Universidad de Costa Rica San José, Costa Rica.

Michel Foucault (2008). Topologías", Fractal n 48, enero-marzo, año XII.

Vauthier Bénédicte (2004). Arte de escribir e ironía en la obra narrativa de Miguel de Unamuno. Ediciones Universidad De Salamanca. 